\title{
長門一宮住吉神社本殿の建築年代とその特質 THE BUILT AGE AND CHARACTERISTIC OF NAGATO SUMIYOSHI SHRINE
}

\author{
中村泰 朗* \\ Yasuo NAKAMURA
}

\begin{abstract}
Nagato Sumiyoshi is one of important shrines in the history of Japanese architecture. It is said that it was built in 1370, in the registration of the Agency for Cultural Affairs. But, as a result of considering the old documents and ornamental details, especially flog legs, I guess that it was rebuilt in 1578. And it has a lot of unique design, for example uchinori-nageshi which is used on pillars of eave.
\end{abstract}

Keywords : Shrine, Construction age, Local style, Detail designs, Flog legs, Uchinori-nageshi 神社，建築年代，地方色，細部意匠，本墓股，内法長押

\section{一、はじめに}

長門一宮住吉神社は山口県下関市に鎮座する有力神社である。当 社の本殿は九間社流造で屋根に五つの千鳥破風を配した長大かつ秀 麗な中世神社本殿として明治三十六年に特別保護建造物（後に旧国 宝）指定を受け、文化財保護法制定後の昭和二十八年に改めて国宝 に指定されている。しかし当本殿に関する研究はあまり進んでおら ず、わずかに概説的なものがあるに過ぎない。そこで本稿は細部意 匠ならびに古文書を検討して建築年代を再考寸るとともに、当本殿 の建築的特質を明らかにすることを目的とする。

当本殿に関する先行研究はまず土田充義氏によるものが挙げられ る ${ }^{1)}$ 。土田氏は当社の来歴や当本殿の規模形式を紹介し、流造と千 鳥破風を組み合わせて連棟春日造本殿まがいの外観を持つ遺構とし て、当本殿は永徳三年（1383）の添御県坐神社本殿（奈良県）とな らび年代的に最も古い例であること、庇部分に用いられる内法長押 が他の本殿に見られない意匠であることを述べている。また当本殿 は神座側面に戸口を開いている点など内部にも特異性を見出すこと ができ、現形式の成立時期や前身本殿の実証的研究は神社建築史上 でかなり問題になると述べている。この他には稲垣榮三氏が屋根に 千鳥破風を冠する連棟本殿の代表として当本殿を紹介している ${ }^{2)}$ 。 稲垣氏は千鳥破風を持つ本殿で現存最古例は正平十八年（1363）の 錦織神社本殿（大阪府）で ${ }^{3)}$ 、これに引き続き十四世紀後半頃に大 阪南部から山陽道にかけて多くの実例を残していること、全ての例 には当てはまらないものの、一つの千鳥破風が一つの神座を象徵し ていることを述べている。

\section{二、住吉神社本殿の沿革と概要}

\section{(一) 本殿の概要}

まずは簡単に当本殿の規模形式を述べておく
（図 1 ～5）。当本殿
は九間社流造であり、方一間の神座（内陣）五室を相の間四室で連 結した身舎の前面に、庇（向拝）を九間連続で付した形式である。 身舎の正側面に迴縁を設け、神座の前にのみ木階を降ろす。庇柱よ り外側に浜縁を、庇柱より内側を長押一段分高くして浜床とする。 身舎は円柱、平三斗を用い、神座正面柱間のみに本蟇股を入れる。 庇では面取角柱、出三斗を用い、九間全てに中備として本蟇股を入 れる。また庇では九間連続して内法長押が打たれている。屋根は檜 皮莫で、神座の上に千鳥破風が都合五箇所置かれている。なお現在 の祭神は西（向かって左）から順に第一殿・住吉三神、第二殿・応 神天皇、第三殿・武内宿祢命、第四殿・神功皇后、第五殿・建御名 方命とする。

\section{（二）住吉神社の沿革}

当社の創建は伝説によると神功皇后の三韓征伐まで遡るといわれ ているが、確実な歴史書に見えるようになるのは平安時代になって からである。『三代実録』によると貞観元年（859）正月に当社の神 階が従五位下から従五位上に進められ、その後貞観十七年に従四位 上、仁和二年（886）に正四位下、『日本紀略』にも寛平三年（891） に正四位下から位一位を増進されたことが記されている。延長五年 （927）にまとめられた『延喜式』の神名帳に名神大社として記載さ れており、当社は少なくとも十世紀には朝廷から崇敬された有力大 社へと成長していたことが分かる。

平安時代末期になると、当社は長門一宮として認知されるように なる。中世一宮制の成立は全国的には十一世紀末から十二世紀初頭 と見られているが、当社の一宮としての初見は『永昌記』4) の嘉承 二年（1107）四月二十八日条である。ここには長門一宮神宮寺の別 当僧侶が神祇官の移に預からないとの申文が出されたことが見えて おり、少なくとも嘉承二年には長門一宮として確立していたと考え られる。

\footnotetext{
本稿の内容の一部は，中村泰朗 $「$ 長門国一宮住吉神社本殿の建築年代の再考」(日本建築学会大会学術講演梗概集 (東海)2012)で発表している。

*広島大学大学院文学研究科 大学院生 Graduate Student, Graduate School of Letters, Hiroshima Univ.
} 


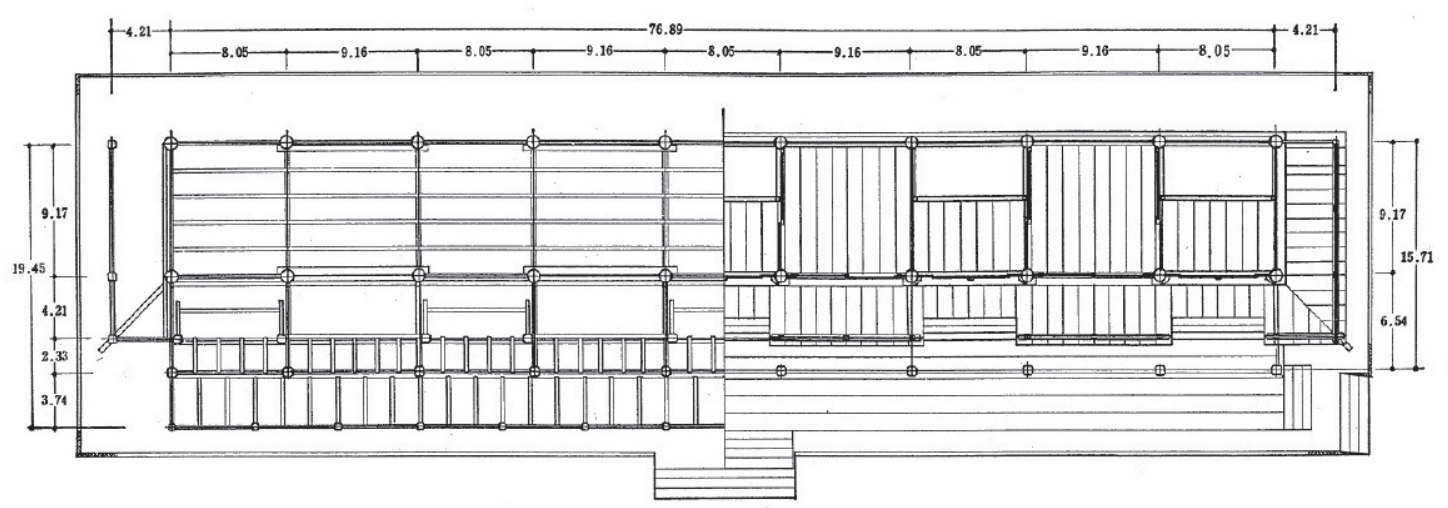

図 1 住吉神社本殿平面図

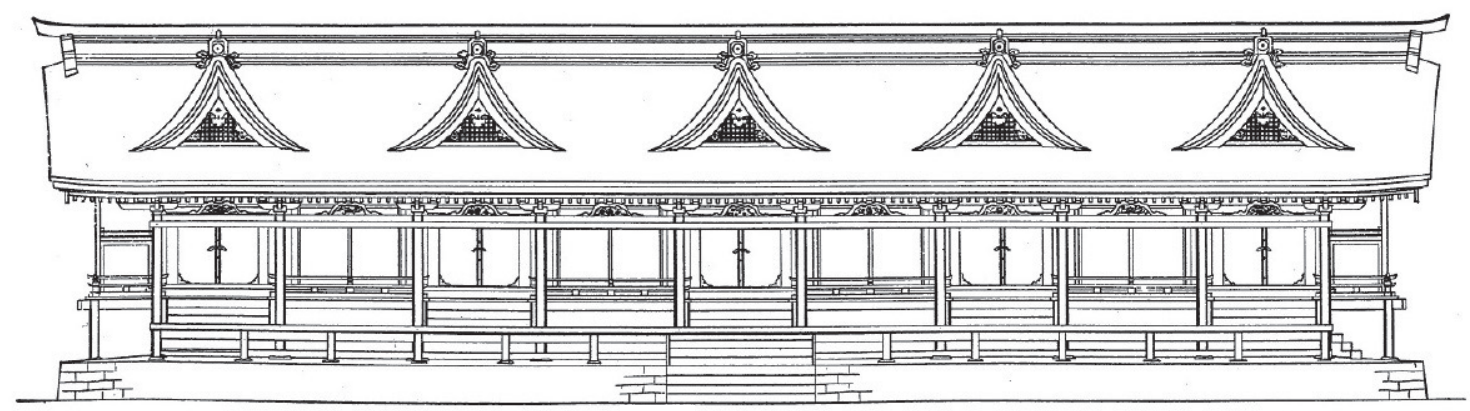

図 2 住吉神社本殿正面図

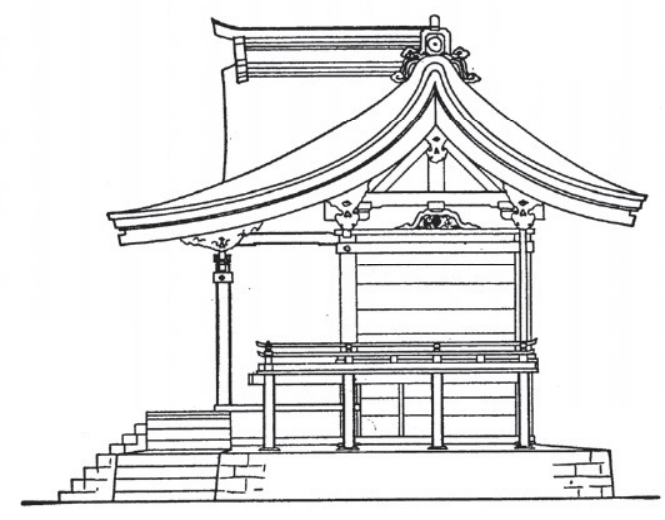

図 3 住吉神社本殿側面図

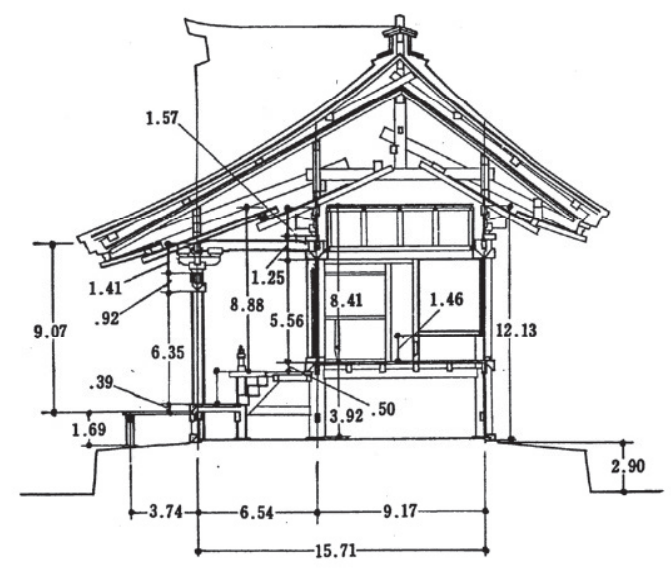

図 4 住吉神社本殿梁間断面図

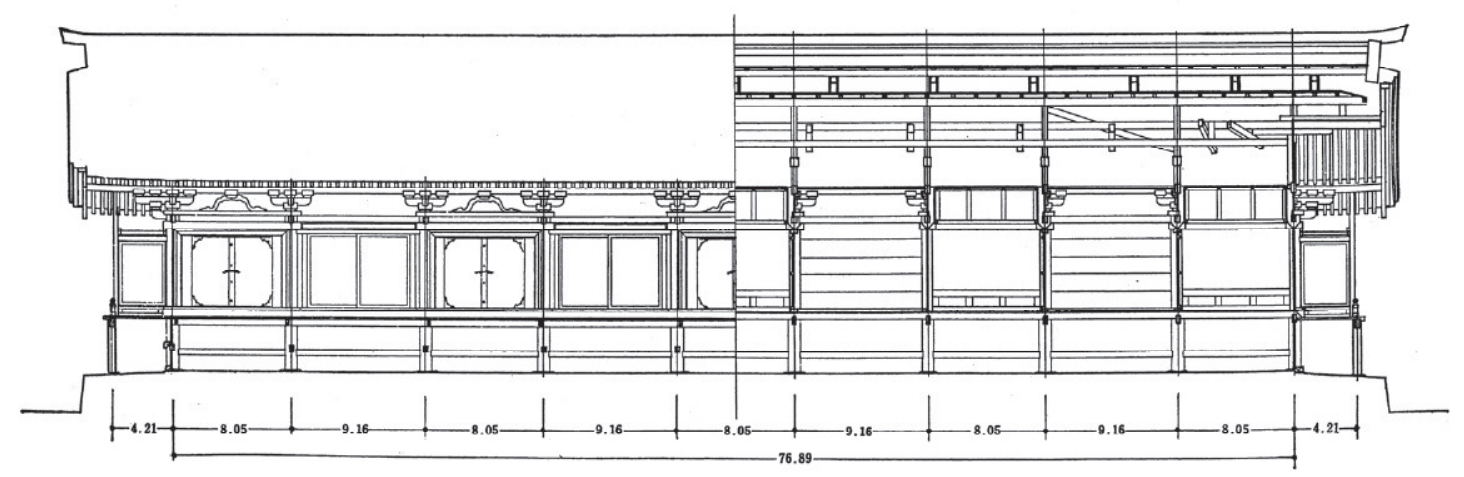

図 5 住吉神社本殿栴行断面図 


\section{（三）本殿の沿革}

建武三年（1336）の「長門国一宮大宮司貞近等申状写」5)には、 正応年間（1288～92）に遷宮をした後に神殿が破壊され、文保年間 （1317～19）に日野大納言が国司であった時に仮殿を造り、嘉暦元 年（1326）に仮殿遷宮まで行われ、正殿造営の沙汰を得るために国 方より奏聞したり武家より目代に触れられたりしたが、仮殿のまま 数年を送り、神体神宝が雨露に侵されてしまった。先々の目代等の 請文に任せ、正税で造営を遂げられないのであれば、料足（造営料） を社家に寄せて造営を遂げるのかどうか沙汰を経られることを望む ことが述べられている。当社の本殿の造営が滞った原因は、戦乱に より在地領主が自立性を強め、国衙の命令に従わなくなり造営費用 の調達や神事・祭礼料の確保が難しくなっていたこと、神社の社領 を在地領主が押領したことなどが考えられる。十四世紀の長門国は 南北朝の動乱に加え、厚東氏と豊田氏による覇権争い、さらに大内 氏の侵攻によって戦乱続きであった。このような中で当社の正殿造 営費用が集まったとも思えず、その後の応安三年（1370）再建時ま での当社には正殿はなく仮殿があるのみだったと考えられる。

周防国の支配者であった大内弘世は、応安三年に長門国を制した ことを記念して当社を再建し祭礼を行っている。この時に彼が奉納

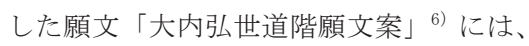

所謂九間一面宝殿并三間申殿、相励新造、至御供所横殿廻廊者、 先構仮屋、沽洗中澣候遷宮既畢

とあり、九間一面の宝殿 (本殿) と三間の申殿を新造し、御供所、 横殿、廻廊は仮屋を建てて遷宮を行ったことが記されている。大内 氏の厚い保護を受けた後、当社は毛利氏の支配下に置かれるように なる。江戸時代には長府毛利氏により社殿の修理を受け、安永四年 （1775）、文化十三年（1816）、嘉永三年（1850）、文久二年（1862） に本殿の上莫が行われている ${ }^{7)}$ 。その後明治四年に国幣小社に列せ られ、同四十四年に官幣中社に昇格している。

\section{三、建築年代の再考}

\section{(一) 文献の再検討}

文化庁の登録では、当本殿の建築年代は「長門国守護職次第」8) によって応安三年とされている。同文書には「井代大内介殿弘世御 法名道階（中略）同御代社頭皆造御遷宮。応安三年三月十一日御出 仕有之。」とあり、また前掲の応安三年の「大内弘世道階願文案」に は、この時建てられた本殿が「九間一面」すなわち現状と同じ平面 形式であることが記されている。さらに後述するように当本殿の細 部意匠が正しく年代判定されていないこともあって、一部の本蟇股 が取り替えられてはいるものの ${ }^{9)}$ 、応安三年の部材がほぼ残ってい ると考えられており、当本殿の建築年代について疑問を持つ研究者 はいなかった。しかし本蟇股の意匠を見ると当本殿の建築年代は到 底納得できるものではない。そこで古記録ならびに本蟇股の意匠に よって当本殿の建築年代を再考していきたい。

当本殿の建築年代を考えるうえで注目できるのが応永三十三年 (1426) の「長門国一宮御笠暴日記案」(以下「御笠日記」) ${ }^{10)}$ である。 ここには当社に用いる御篻の注文が記されており、

案

一宮御簾日記 内御笠

$$
\begin{aligned}
& \text { 長一丈一尺五寸 } \text { 弘同之、 } \\
& \text { 外御笠 } \\
& \text { 長一丈五尺 } \\
& \text { 弘一丈一尺五寸、 }
\end{aligned}
$$

右此前、一社別二枚アテタルヘく候、委細大宮司方申談、令注 進之候、

$$
\text { 応永井三九月廿七日周音 在判 }
$$

中村殿

宮殿金物八何も結構候之間、目出候

とあって、内御笠は長さ、幅ともに一丈一尺五寸、外御笠深長さ一 丈五尺、幅一丈一尺五寸であったことが分かる。

この内御䇥・外御笠にこつてだが、当時の長門国主大内義興が当 社の各祭神に奉納した神宝を記した記録である大永六年（1526）の

「長門国一宮御神宝物調進送文案」11）を見ると、

貢上

御斎籠御神宝物調進送文事

合

一宮住吉大明神御料

(中略)

御簾三枚内 内一枚錦額向

荒魂御料

(中略)

御簾三枚内 内一枚錦額向

御蔭御料

(中略)

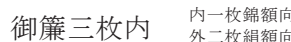

妹母宮御料

（中略）

御簾三枚内 外三枚綿䫅向向

武者殿御料

(中略)

御簾二枚内 内一枚錦額向

とあり、当本殿では神宝として内御笠、外御篻が調進されていたこ とが分かる。また第一神（一宮住吉大明神）から第四神（妹母宮） までは内御篻を一枚、外御篻を二枚とし、第五神（武者殿）のみは 内・外御筝ともに一枚ずつ献じたことが記されており、内御策は計 五枚で現本殿の神座の前すなわち身舎扉の戸口数と、外御笠は計九 枚で現本殿の庇の正面柱間と一致する。よって大永六年当時の本殿 の平面形式は九間一面であり、内御笠棌身舎扉の戸口に、外御笠棌は 庇の正面に掛けた可能性が高いといえる。そして当本殿は遅くとも 応安三年の時点で既に九間一面の平面形式をもち、大永六年の時点 ならびに現状でも平面形式に変化がないことから、応永三十三年当 時の本殿の平面形式も九間一面であったとしてよい。さらに一般的 な神社本殿の例の通りに内御簾を祭壇の前、外御箑を身舎扉の戸口 に掛けたとすると、身舎の内法高が一丈五尺ほどになってしまい、 神社本殿にしては異様なほど高くなる。以上のことから応永三十三 年当時も内御策は身舎扉の戸口に、外御笠嵲庇の正面に掛けたと判 断できる。

次に現本殿と御策の大きさを比較検討してみたい。現本殿は神座 正面が柱真々で八尺五分 ${ }^{12)}$ 、身舎内法長押下端から床までが五尺五 寸六分、庇内法長押下端から床までが六尺三寸五分である。御䇥は 
柱と柱の内側に掛けるため、御笠の幅は少なくとも神座正面の柱間 寸法より短くてはならない。しかし「御笠日記」に記載された御笠 の幅は内御笠・外御笠萐ともに一丈一尺五寸で、現本殿の神座正面の 柱間寸法より 1.4 倍ほど長く、これでは御笠をを掛けることは不可能 である。また御笠は余分に長く作って床に垂らして曲げておくよう な用い方はせず、その長さは内法高とほぼ同等となる。よって「御 簾日記」に記された御策の長さは、応永三十三年時の本殿の内法高 とほぼ同等の值であるといえる。そこで御篻の長さと現本殿の内法 高を比較すると、内御笠は現本殿の身舎内法高のおよそ 2 倍、外御 篻は庇内法高のおよそ 2.3 倍となることが分かる。

以上より応永三十三年当時の本殿は現状を比べると、九間一面と いう平面形式こそ等しいものの、平面では神座正面の柱間がおよそ 1.4 倍、内法高に至ってはおよそ 2 倍以上であり、大きさが全く合 わないことは明らかである。よって当社の本殿が応永三十三年以降 に造替もしくは滅失によって再建されたことは確実であろう。

\section{（二）本殿の修理の経緯}

次に応安造営以後の当本殿の修理の経緯を見ていくと、まず永享 九年（1437）の「大内氏奉行人連署書状案」13) や同十年の「鹑頭弘 忠書状案」 ${ }^{14)}$ などには屋根上莫のための檜皮や竹釷に関する記述が

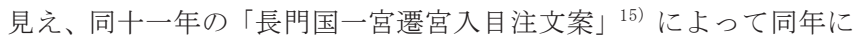
上莫が終了して遷宮が行われたことが分かる。享禄四年（1531）の 「大内氏奉行人連署奉書」16)には、

当社領段銭事、去年以来被拘置、被致愁訴候、社家及大破候之 間、御造営事、至京都可有御注進之由候、御宝殿上莫事者、入 目可為参百五拾六貫百五拾文之由、檜皮大工注申候

とあり、本殿を造営し、屋根に檜皮を莫くために必要な段銭につい て注進したことが記されている。また天文四年（1535）の「後奈良 天皇綸旨」 ${ }^{17)}$ にも当社の造営に関寸る記述が見られる。当本殿神座 内の天正五年 (1577）の墨書 ${ }^{18)}$ によると「営社御再興之砺五社御 本地垂迹跡共如往昔書畢」とあって、当本殿を再興した際に本殿内 部の壁面に、本地仏と垂迹神を往昔の如く書き終わったことが述べ られており、同六年の「毛利輝元書状」19) を見ると同年四月十日に 上葺が終了して遷宮が行われたことが分かる。

以上より当本殿は応安造営以後、永享十一年、享禄四年頃、天文 四年、天正六年の四回ほど修理が行われたことが分かる。永享十一 年の修理は、竹釷や檜皮の注文に関寸る記録が多く残ることから屋 根の莫き替えが行われたことは明らかである。次に享禄四年頃の修 理は「大内氏奉行人連署奉書」に見える三百五十六貫百五十文とい う金額から、屋根の莫き替えは行われたものの、本殿全体の造替と いった大規模な工事が行われた可能性は低いと思われる。また天文 四年の修理に関しては享禄四年頃の修理からそれほじ時間も経過し ていないことから、小規模な工事であったことが予想される。最後 の天正六年の修理については本殿内の墨書に「再興」と記されてい るのが注目される。再興という語には一般的に建て直すという意味 か大修理を施すという意味がある。これまでの修理が屋根の莫き替 えのみを行う比較的小規模な工事であったこと、応永三十三年以降 に本殿が再建されたはずであることを考えれば、ここでの再興の意 味は前者の意味であり、当本殿の再建年代も天正六年の可能性が高 いと考えられる。

\section{（三）本蟇股の意匠}

最後に本蟇股の意匠を検討することで、先ほど述べた当本殿の再 建年代を確認したい。まず近畿地方の本蟇股をみると、脚部は時代 が下降するにつれて足首と上部の太さが均等になる。肩の繰形にお いて、十四世紀では斗尻から数えて一筆目に対して二筆目がかなり 小さかったのが、十五世紀以降になると二筆目の発達に伴って一筆 目之二筆目の大きさがほぼ等しくなる。また十四世紀は二筆目が水 平に少しだけ出て急に下っていくが、十五世紀以降になるとなだら かに下るようになる。また足元は徐々に大きくなる傾向をもつ。内 繰の曲線で、斗の下にあたる部分は十四世紀のものは一筆が多く、 二筆の場合は一筆目がかなり長い。十五世紀のものは二筆が一般化 するが一筆目が次第に短くなる。しかし十五世紀までのものが茨を 除いて一筆目と二筆目はほぼ直線的であるのに対し、十六世紀後期 になると一筆目が短くなって二筆目と同じくらいになり、二筆目を 大きく盛り上げるようになる。以上のことは正平十二年（1357）の 長保寺多宝塔（和歌山県）の本幕股（図 6)、文明四年（1472）の円 成寺本堂㕌子 (奈良県) の本蟇股（図 7)、永禄二年（1559）三郷八 幡神社本殿（和歌山県）の本蟇股（図 8）を比較すると分かるだろ う。

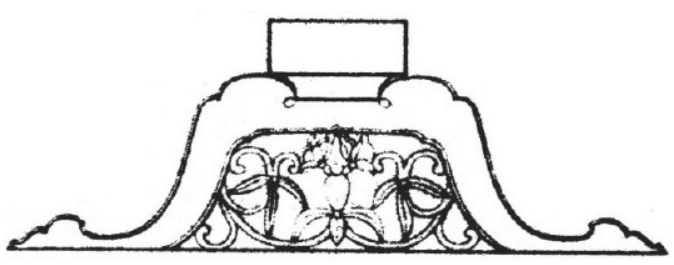

図 6 長保寺多宝塔本㱳股

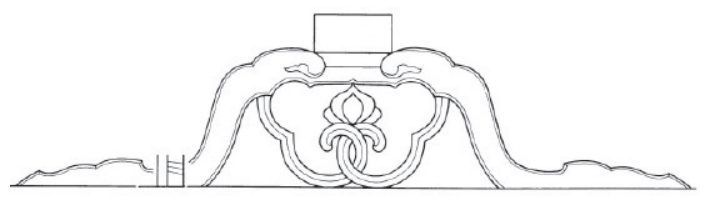

図 7 円成寺本堂厨子本蟇股

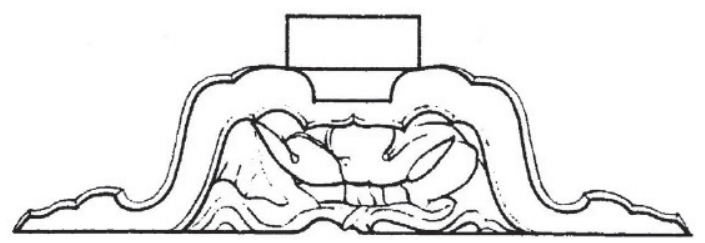

図 8 三郷八幡神社本殿本蟇股

次に山口県の本㱳股を検討してみたい。まず室町中期とされてい る平清水八幡宮本殿（山口市）の本蟇股（図 9）をみると、肩の曲 線は斗から数えて二筆目が小さく水平に出て急に降っており、内繰 の曲線も一筆目、二筆目ともにほぼ水平であるが、二筆目が一筆目 より長い。平清水八幡宮本殿の本蟇股と中央の例を比べると、肩の 繰形は十四世紀の特徴と一致するが、内側の繰形は十五世紀のもの に近い。したがって平清水八幡宮本殿の例は十五世紀のものと判断 される。細部意匠の一部に古式が残るのは、山口県が中央と離れた 地方にあるためと考えられる。永正十七年 (1520) の八坂神社本殿 (山口市) の本蟇股（図 10）では、肩の二筆目がやや大きくなって 
おり、内繰の曲線は下方に向けて円弧を二つ連ね三筆目を上方に大 きく突き出した円弧とする。斗の下の曲線を中央の例のように反転 曲線とせず円弧を二つ連ねるのは、室町後期以降の山口県の本蟇股 の特色と考えられ、この他に䦚伽井坊多宝塔 (下松市)、古熊神社本 殿（山口市）などに用いられている。

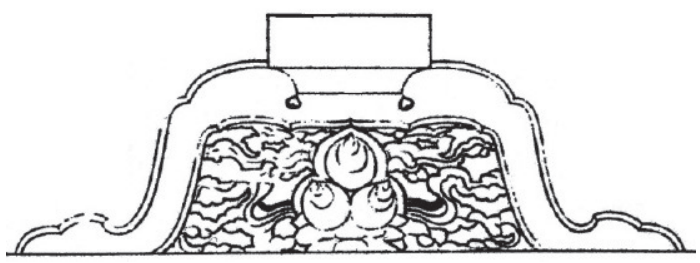

図 9 平清水八幡宮本殿本蟇股

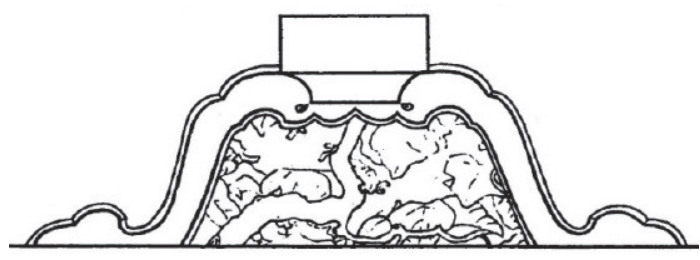

図 10 八坂神社本殿本蟇股

ここで当本殿の身舎ならびに庇中央間以外の本墓股（図 11、12） をみると、八坂神社本殿のものと比べて内繰の曲線の二筆目がさら に大きく盛り上がっていることが分かる。このことにより少なくと も永正年間より後の作成と考えられる。さらに肩の二筆目が大きく 滑らかに下っている点、足元が極めて大きい点を加味すれば当本殿 のものは永正より年代が下降し十六世紀中期以降の意匠を持つとい えるだろう。

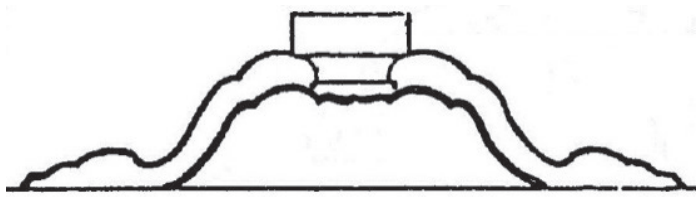

図 11 住吉神社本殿身舎本㱳股

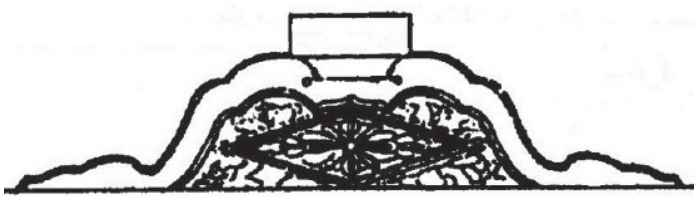

図 12 住吉神社本殿庇中央間以外本幕股

最後に庇中央間の本蟇股（図 13）についてだが、土田氏は、「こ の蟇股は他の八個の蟇股と形式がやや異なり、両脚が下方になるに したがって細くなり、肩が強調され、室町時代末期の特徴を示して いる。そのことから、この蟇股は弘治三年以降の毛利元就の繁栄の 時期に、毛利氏が本殿等の修理を行い、その際に応安造営の㱳股と 取替えたものと推定される」 ${ }^{20)}$ としている。両脚が下方になるにし たがって細くなるという指摘は当を得ていないが、足元が大きくな っている点や内繰の曲線の特徵などをみると十五世紀の特徴を持っ
ている。したがって、これ以外の本蟇股よりかえって古式ではある が、内部彫刻に三星一引の毛利氏の家紋が加えられていることから、 弘治三年（1555）の毛利元就の覇権成立時から天正六年までの間に 元就あるいは隆元、輝元によって取り替えられた可能性も否定でき ない。

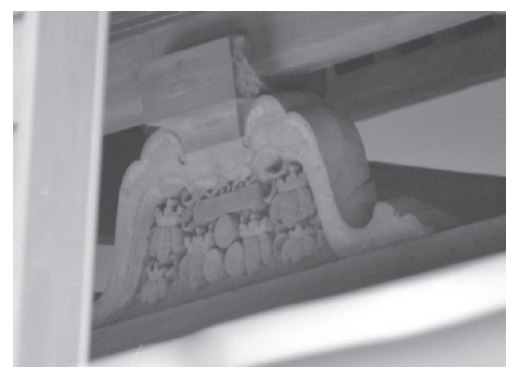

図 13 住吉神社本殿庇中央間本蟇股

以上より当本殿の本蟇股は、身舎のものならびに庇中央間以外の ものが十六世紀中期以降の意匠をもち、庇中央間のものに関しては 毛利氏による取り替え材の可能性が高い。よって本摹股から推定で きる当本殿の再建年代は十六世紀中期以降と考えられる。そこで先 ほど述べたことと合わせて考えれば、当本殿の再建年代は天正六年 と判断できる。

\section{四、現本殿の特異な形式}

\section{(一) 古式な形式}

ここからは当社の本殿の特異な形式について考察を行う。以降、 応安造営の本殿を前身本殿、天正再建の本殿を現本殿と呼称するこ ととする。現本殿の特徵として古式な形式を持つことが挙げられる。 (イ) 組物

現本殿の身舎組物は平三斗を用いており、妻虹梁は身舎正面柱上 の平三斗の巻斗に組み込まれ、平三斗上の軒桁を固定する役割も兼 ねている。柱上の大斗の上に梁間方向に内側に肘木が出され、この 上に巻斗を置くことで虹梁を受け、肘木の外端は鯖の尾として突出 させる（図 3）。このような形式は平安末期の宇治上神社本殿の右殿 の庇に既に用いられており、仁治二年（1241）の姿を伝えていると いわれる厳島神社本社本殿では正面庇の両端の夕現本殿と同様の形 式を持っている ${ }^{21)}$ 。

現本殿に用いられている鯖の尾付き平三斗の形式が平安時代末期 には成立していたのに対し、身舎に出三斗を応用する形式は十五世 紀頃になって流行する。早い例では永徳三年の添御県坐神社本殿が あるものの、応永十年 (1403) の八幡神社本殿（兵庫県宝塚市）、同 二十年の広八幡神社本殿（和歌山県）など、出三斗を身舎に用いた 例が十五世紀以降に増えている。以上より現本殿に用いられている 組物の形式は、天正六年再建ながら古式を踏襲しているといえる。 (口) 軒

この他に古式な形式として正面の垂木が挙げられる。現本殿では 身舎の飛檐垂木を打ち越して庇の地垂木とし、さらに庇にて飛檐垂 木を打って二軒繁垂木とする（図 4)。三間社流造で最も古制を伝え ているといわれる上下賀茂神社本殿では、正面垂木は身舎を地垂木 と飛檐垂木の二軒繁垂木とし、この飛檐垂木上に打越垂木を打って 
庇を一軒疎垂木とする。その後鎌倉時代後期とされる宇治神社本殿 (京都府)に始まり、中世を通じて多くの本殿で現本殿と同様の形 式が用いられている。三浦正幸氏によると現本殿のような垂木の用 い方は鎌倉時代後期にはすでに出現し、流造の一般的形式になった としている ${ }^{22)}$ 。次に身舎の地垂木を庇へ打ち越し、庇のみを二軒と した形式が生まれている。早い例としては応永三十四年（1427）の 伊予一宮大山祇神社本殿があり、その後十六世紀初期あたりから多 く用いられるようになっている。

上下賀茂神社などを見れば分かるように諸国一宮などの社格の高 い神社では古式な形式が遵守されており、現本殿も長門一宮として の社格の高さから古式な形式を持っていると考えられる。また山口 県では室町中期の平清水八幡宮本殿、文亀三年（1503）の今八幡宮 本殿でも、現本殿と同様に身舎に平三斗を用い梁方向にも肘木を加 えて外端を鯖の尾とする形式を持っている。三浦氏は中世の山口県 は中央とは異なる独自の建築文化を持っていたことを述べているが 23)、現本殿などに用いられる古式な形式は、長門国という地方ゆえ に時代の好みに後れが見られるということが指摘できる。

以上述べてきたとおり現本殿には天正六年再建にしては古式な構 造形式が踏襲されている。しかし構造形式自体は古式であるが、本 蟇股の曲線や肘木の曲線といった細部意匠には時代の好みが現れや すく、現本殿の本蟇股には十六世紀中期以降の好みが明確に現れて いる。また前述の古記録の検討からも現本殿の建築年代は天正六年 とするのが妥当であろう。

\section{(二) 連三斗下の持送り}

現本殿では身舎、庇の両端の組物に連三斗を用いている。一般的 な連三斗では最下部の木鼻や肘木の下には何も入れることはないが、 現本殿では身舎・庇ともに実肘木型の持送りを用いている(図 14)。 現本殿の身舎では神座の頭貫の上にのみ台輪を置いており、連三斗 の大斗はこの台輪の上に置かれている。このため一般的な連三斗の ように頭貫の位置で下段肘木を形成すると、大斗と下段肘木の先端 の斗の位置が合わなくなり不都合が生じてしまう。それ故に現本殿 身舎では下段肘木を台輪の上端に合わせて挿すようにして大斗と先 端の斗の高さのずれを解消している。そして下段肘木は柱との付根 で台輪の成だけ欠かれており、このために実肘木型の持送りを用い て補強したと考えられる。

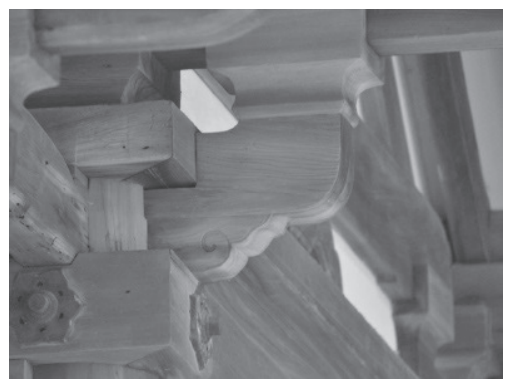

図 14 住吉神社本殿連三斗下持送り

庇の実肘木型の持送りは極めて小さい部材であり、風食や虫害の ため辛うじて実肘木型であることが分かる程度である。庇では頭貫 の寸ぐ下に内法長押を打つため下段肘木の下に大きな持送りを入れ るのは難しいが、おそらく身舎の意匠を参考にして庇にも用いたも
のであろう。三浦氏は山口県南部の中世社寺建築に用いられている 実肘木や虹梁下などに用いられる実肘木型の持送りは成・幅ともに 他の地域と比較して異様なほど断面の小さいものを用いていること を指摘している ${ }^{24)}$ 。よって現本殿において連三斗の下に小さな持送 りを入れることも山口県の地方色の一つということができる。また 社寺建築における地方色は十四世紀後半頃から見られるものといわ れており、山口県の場合は元応二年（1320）の功山寺仏殿の身舎で 既に現れている ${ }^{25)}$ 。このことからすれば前身本殿の頃から、小さい 実肘木型の持送りが用いられていた可能性が指摘できる。

\section{（三）神座側面の戸口}

次に神座側面に設けられた戸口について述べる。現本殿では中央 の第三殿は両側面に戸口を設け、第三殿以外は相の間方向に片方の み戸口を設けている（図 1)。方一間の相の間を用いて連棟とした形 式で、神座側面に戸口を設けた例は管見ながら現本殿しか見当たら ない。

ところで中世の流造本殿では身舎の側面に戸口を開いたものが現 れており、古くは徳治三年（1308）の苗村神社西本殿など十四世紀 のものにも用いられている。身舎側面に戸口が開かれた理由の一つ として、神と人が正面の扉を共用することを避けたことが挙げられ る。御戸開きや献饌などの正式な祭祀では正面の扉を用い、神職が 本殿へ参入する通路口として側面の戸口を用いたと思われる。山口 県の神社本殿の多くが身舎側面に人が通るための戸口を設けられて いることを考えれば、現本殿でも同様の目的で神座側面の戸口を設 けたと推察できる。

土田氏はこの戸口の配置ついて、中央の第三殿のみ両側面に戸口 が設けられ左右の相の間を専用的に利用していることから、第三殿 が著しく優遇されていると述べている ${ }^{26)}$ 。しかし文明十二年 (1480) の飯尾宗祇の紀行文『筑紫道記』 ${ }^{27)}$ に宗祇が当社の祭神の並びを記 しており、これを見ると主祭神の住吉明神は西の第一殿に祀られ、 第三殿は高良大明神である。この頃には現在の祭神の配置と同じで あることから、天正六年の再建の時点で第三殿が主祭神の神座であ った可能性は低く、第三殿が優遇される理由は見当たらない。

そこで戸口は神職が神座に参入するための通路口であるというこ とを踏まえてその配置について考えてみると、第三殿については本 殿の左右対称性を守るためには両側面を戸口とするしかない。第一 殿と第五殿については身舎の外側に戸口を開くと、玉殿の安置され た祭壇が直に外界に晒されてしまうために都合が悪い。よって第一 殿と第五殿は内側すなわち相の間の方に向かって戸口を開くしかな い。第二殿と第四殿についてはもし内側に戸口を開くと、第二殿の 内側から第四殿の内側まで戸口が連続して並ぶことなる。このこと を避けるために第二殿と第四殿は外側に戸口を開いたと考えられる。 以上より戸口の配置は必然的に現状のようになったものであり、土 田氏の述べるように特に第三殿を優遇させようとしたものとはいい 難い。なお前身本殿に神座側面の戸口が存在したかについては資料 が不足しており明らかにすることはできない。

\section{五、現本殿の建築的特質}

\section{(一) 前身本殿の規模形式}

現本殿の建築的特質について考察する前に、前身本殿の規模形式 を考えてみたい。まず前身本殿の平面については前述したように応 
安造営時から九間一面であった。また「長門国一宮御神宝物調進送 文案」に五柱の祭神に神宝を献納したことが記述されていることか

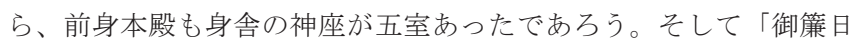
記」より推定できる前身本殿の身舎の神座正面柱間はおよそ一丈一 尺五寸である。もし相の間の正面柱間が現状のまま（九尺一寸六分） と仮定すると、前身本殿の全長はおよそ九丈四尺（現本殿は七丈六 尺八寸）となる。この大きさは切妻造系の本殿で現存最大の正面規 模をもつ厳島神社本社本殿（広島県、およそ七丈八尺）を凌駕する ものであり、また前述の通り内法高も現状の二倍ほどあったと考え られることから、前身本殿は現本殿より遙かに巨大かつ神社建築史 上類例のない長大な本殿であった可能性が考えられる。

屋根形式についての記述はないが、九間一面という平面を考えれ ば入母屋造であった可能性は低く、現本殿と同様流造であったと考 えられる。神座の上の千鳥破風については一切記述されておらず前 身本殿の頃からあったのか不明である。なお前身本殿の庇の形式に ついては次節で述べる。

\section{(二) 庇に関する考察}

流造本来の庇の形式は上下賀茂神社本殿などに見られるもので、 庇の内部に身舎廻縁から一間の木階を降ろし、庇の屋根を正面柱間 全体に広げた形式である。この場合の庇は木階が雨に濡れないよう にするためのもの、寸なわち向扯であると同時に、木階下で人が拝 礼や儀式を行うためのものであったと考えられる。その後鎌倉時代 になると徳治三年の苗村神社西本殿の庇に代表されるような、身舎 より少しだけ低く床を張り建具など周囲を覆って外陣 ${ }^{28)}$ とした形 式が生まれる。そこで現本殿の庇を見てみると、内部に木階を設け 建具を入れず開放的に扱っていることから、上下賀茂神社本殿のよ うな流造本殿本来の庇の形式に近いもののように見える。しかしこ の形式で庇に内法長押を打っているものは管見ながら他に例がなく、 現本殿の庇の内法長押の使用について説明することが難しい。ここ では現本殿の特異な庇の意匠について考察を行い、内法長押の意義 を明らかにしていく。

前掲の「御笠日記」ならびに「長門国一宮御神宝物調進送文案」 によって、前身本殿の頃は庇正面に御䇥が掛けられていたことが予 想される。さらに現本殿で庇正面に現状では不必要ともいえる内法 長押があることから、前身本殿の頃にも庇の正面に内法長押を設け ていたと思われる。また内法長押があり、御笠まで掛けられていた ということは、前身本殿の頃は庇の正面に部などの建具が入ってい たと予想できる ${ }^{29)}$ 。そして正面が以上のような意匠であるのに側面 を吹放ちとするのは普通考えられないので、側面にも内法長押ある いは鴨居を廻し建具等が用いられていたはずである。よって前身本 殿は上下賀茂神社本殿のような流造本来の庇の形式を持つものでは なく、鎌倉時代以降に各地に見られるようになった外陣付き流造本 殿であったと考えられる。また平清水八幡宮本殿や今八幡宮本殿な ど現存する中世の山口県の流造本殿は全て建具などを用いた外陣付 きであり、奥行き三間の一間社春日造である石城神社本殿や正面三 間側面二間の入母屋造である古熊神社本殿も前面を外陣とした形式 である。よって中世の山口県の神社本殿は内部を前後二室に分けて 内陣と外陣を設けるのが主流であったということができる。

ここで注意すべき点は、「御篻日記」によると庇の内法長押に掛け られていた外御䇥の方が、身舎扉内側に掛けられていた内御箑より
三尺五寸も長いことである。一般的な流造本殿の身舎廻縁の木階の 高さは三尺から四尺ほどが多く、この寸法から考えると前身本殿で は庇の内部に木階が設けられていた可能性が指摘できる。このこと について参考になるのが十四世紀後期頃の建築と考えられている三 島神社本殿（愛媛県東温市） と応永三十四年の大山祇神社本殿であ る。三島神社本殿は上下賀茂神社本殿のような一般的な三間社流造 本殿で、一方大山祗神社本殿は三間社外陣付き流造本殿で、庇内部 に身舎に上がるための木階を設けた形式である。三浦氏は三島神社 本殿の旧状を痕跡により復元し、その旧状は庇の両側面が現在のよ うに開放されておらず、板壁で閉鎖され片方に方引きの戸があった こと、正面は建具が入っていない開放的なものであったことを明ら かにした ${ }^{30)}$ 。そして両本殿の差異から、外陣付き流造本殿はまず迴 縁と浜床から成る庇部分を板壁などで囲って外陣とし、次の段階で 外陣の床の高さを苗村神社西本殿のように迴縁に近い高さ、または 大山祇神社本殿のように浜床に近い高さで統一寸ることでできたと 推察している ${ }^{31}$ 。

応安三年の住吉神社前身本殿は庇の内部に木階を設けているのに 対し、中世の山口県の外陣付き流造本殿は全て外陣の床高を廻縁の 近くに統一した形式である。上記の三浦氏による推察を参考にすれ ば前身本殿は三島神社本殿の旧姿のように外陣付き流造本殿の古い 形式であり、その後、山口県の外陣付き流造本殿では外陣の床高を 廻縁の近くに統一したものと考えられる。前身本殿と三島神社本殿 は建築年代が近く、また両社ともに中央から遠く離れた場所に鎮座 していることから外陣付き流造本殿の古い形式が残ったと思われる。 前述したように現本殿は前身本殿と比較して柱間寸法と内法高が 大幅に縮小されている。おそらく天正再建時の毛利氏の財力の問題 などがあって縮小せざるを得なかったと思われる。また本殿を縮小 する際に庇の形式を改めたと考えられるが、庇正面の内法長押まで 撤去してしまうと、この部分が外陣であることが分からなくなって しまう。よって現本殿の庇の内法長押は庇が外陣であることを示す ために残されたものと考えられる。

\section{六、おわりに}

本稿は長門一宮住吉神社本殿の建築年代を再考し、その建築的特 質について検討を加えたものである。応永三十三年の「御笠日記」 に記されている御策の大きさと現状の大きさが全く合わないことか ら、現本殿は応安造営の本殿を縮小して再建されたことは間違いな く、その再建時期については文献と本蟇股の意匠から天正六年と推 定した。

現本殿の建築的特質については、身舎の組物に平安時代末期には 成立していた鯖の尾付き平三斗を用いているように、古式かつ独自 の意匠を持っており、長門一宮の本殿としての格の高さを示すと同 時に中央とは離れた長門国にあるために時代の好みに後れた意匠が 見られることを指摘した。現本殿最大の特徵ともいえる庇の内法長 押については、「御笠旦記」ならびに「長門国一宮御神宝物調進送文 案」によって前身本殿の頃は庇に御笠をを掛けていたことが分かり、 当初は庇が建具などを用いて外陣として扱われていた可能性が高く、 現本殿の庇の内法長押はそのことを示寸ものであることを明らかに した。

今回住吉神社本殿について建築年代から検討し直すことで新たな 
知見を得ることができた。本稿によって建築年代が二百年降ること となってしまったが、現本殿は神社建築の発展を考えるうえで貴重 な遺構といえ、その価值は依然として高いものと評価できる。また 今までの神社本殿に関する研究では、その本殿に特徵的な構造や意 匠があっても単なる特色として扱われ深く追及されることは少なか った。しかし現本殿において庇の内法長押が前身本殿の姿を示して いるように、神社本殿の特徵的な意匠には多くの問題が潜んでいる と思われる。今後はこのような点に着目し研究することも重要と考 えられる。

\section{注}

1）土田充義「住吉神社本殿」『日本建築史基礎資料集成』三、社殿 III、pp. 22 ～28、中央公論出版、1981.8。

2）稲垣榮三『神社と霊廟』原色日本の美術 16、小学館、1968.10。

3）錦織神社本殿の細部意匠を見ると、建築年代が下降する可能性が考えられ る。

4）『山口県史』史料編古代所収。「長門一宮神宮寺別当僧侶不可預神祇官移之 由、上卿被難、掲史範定不准退帰」

5）『長門国一八宮住吉神社史料』上巻所収。「於造営者、仮殿・正殿共以国衙 役也、子細見所進文書絵図、爱正応遷幸之後、神殿破壊之間、文保年中日 野大納言家国務之時、被作仮殿、嘉暦元年被遂遷宮畢、正殿事同為有沙汰、 或自国方被経奏聞、或自武家踓被触眼代、于今未道行、且黒木之殿、白地 之構、依送数年、既以神体神宝被侵雨露、御神条宜難測、早任先々目代等 請文之旨、以国衙無正税被遂御造営欺、不然者、被寄別料足於社家、遂其 節哉否、欲被経御沙汰（以下略）」

6)『長門国一宮住吉神社史料』上巻所収。

7）棟札が現存しており本殿の附指定となっている。

8）『続群書類従』第四集、帝王部上所収。

9）土田充義前掲論文（注 1 参照）詳しくは後述する。

10）『長門国一八宮住吉神社史料』上巻所収。

11）『山口県史』史料編中世四所収。なお京禄三年（1530）にも大内義隆が同 様の内容の宝物を献じている。

12) 造営尺が現行尺の 1 尺う $303 \mathrm{~mm}$ より長く、 $305 \mathrm{~mm}$ 程度であったと考えられ、 計画寸法は八尺と考えられる。

13）『長門国一ノ宮住吉神社史料』上巻所収。「一宮御造営檜皮事」

14）『長門国一八宮住吉神社史料』上巻所収。「就一宮御造営檜皮事、条々御 注進披露候了、一竹事、(中略) 一竹釷事、(中略)一かきはい事」

15）『長門国一八宮住吉神社史料』上巻所収。「長州一宮遷宮入目色々注文」

16）『長門国一八宮住吉神社史料』上巻所収。

17）『長門国一八宮住吉神社史料』上巻所収。「長門国一宮造営之事、宜被存 別忠之敬神」
18）『長門国一ノ宮住吉神社史料』下巻所収。

19）『長門国一八宮住吉神社史料』上卷所収。「当社御遷宮、去月十日被遂其 節之由候」

20）土田充義前掲論文（注 1 参照）。

21）正面両端以外は虹梁を大斗に組み込夕、先端を鯖の尾として突出させる 形式としている。正面両端で虹梁を大斗に組み込む形式を用いてしまうと、 身舎内法長押と庇虹梁が交差することになって側面から見た納まりが難し くなるために、正面両端のみ形式を変えたものと考えられる。

22）三浦正幸「神社」『新日本建築学大系』2、日本建築史、彰国社、pp. 248 $\sim 258 、 1999.10$

23）三浦正幸「不動院金堂の研究二（山口より移建の根拠）」『日本建築学会 大会学術講演梗概集』、pp. 2407 2408、1982.10、同『不動院』、広島市教 育委員会、1982.3

24）三浦正幸前掲論文（注 23 参照）。

25）三浦氏は前掲論文（注 23 参照）で功山寺仏殿の身舎に半分に割った挿斗 が用いられていることを指摘している。なお功山寺仏殿の裳階は後世に大 規模な修理が施された可能性が高く、身舎と裳階で細部意匠に大きな差が 見られる。詳しい裳階の修理年代は資料の制約上明らかにできないが、裳 階の海老虹梁ならびに木鼻の意匠から判断すれば十六世紀後期以降と考え られる。

26）土田充義前掲論文（注 1 参照）。

27）『群書類従』第十八集、日記部・紀行部所収。「住吉に明鄭律師諸共に参 れり、(中略) 鎮座の御神は西の第一住吉明神、次八幡大菩薩、高良大明神、 神功皇后、諏訪明神、以上五柱なり」

28）研究者によっては前室とも呼ばれているが、ここでは本来の呼び方に従 つて外陣と呼ぶ。

29）この形式の類例として、天文十年（1541）の武田八幡神社本殿（山梨県） が挙げられる。この本殿は正面のみに内法長押を打ち、引き違いの建具を 入れ、側面に板壁を入れた庇をもっている。また「長門国一宮御神宝物調 進送文案」からは庇に九間連続して御笠声掛けられており、九間連続して 蔀などの建具が入っていたことが予想される。これに対し「御策日記」で は相の間正面の庇に御笠が用いられていたのか判断できないものの、現存 する外陣付きの流造本殿で、庇正面の建具を神座の前とそれ以外で変化さ せている例はないことから、応永三十三年の時点でも庇には九間連続して 部などの建具が用いられていたと考えられる。

30）庇正面には格子戸等の簡略な建具があった可能性はある。

31）三浦正幸「三島神社本殿（愛媛県温泉郡川内町）」『日本建築学会中国 · 九州支部研究報告』第 8 号、pp. 289 292、1990.3。

\section{図版出典}

図 1 5、11、12 『日本建築史基礎資料集成』三、社殿 III（前掲注 1 参照) 所收

図 6 10 文化庁保存図

図 13、14 筆者撮影 